\title{
Study on the Development of Community Based Tourism Coastal Areas (Case Study: Historical Beach in Batu Bara Regency)
}

\author{
Ivany Hidayat $^{1}$, Nurlisa Ginting ${ }^{1,2,3,4}$, Hilma Tamiami Fachrudin ${ }^{1,2}$ \\ ${ }^{1}$ Magister of Architecture, Faculty of Engineering, Universitas Sumatera Utara, Medan, Indonesia \\ ${ }^{2}$ Department of Architecture, Faculty of Engineering, Universitas Sumatera Utara, Medan, Indonesia \\ ${ }^{3}$ Lake Toba \& Sustainable Tourism Working Group, Universitas Sumatera Utara, Medan, Indonesia \\ ${ }^{4}$ Monitering Center of Sustainable Tourism Observatory (MCSTO), Universitas Sumatera Utara, Jalan \\ Perpustakaan Gedung J7, Medan-20155, Indonesia
}

Corresponding Author: Ivany Hidayat

\begin{abstract}
The tourism industry is one of sectors that can help improve the welfare of the community. One of them is the famous Historical Beach in Batu Bara Regency. Historical Beach has opportunity to be developed as marine tourism by involving the community. The purpose of this research is to formulate the concept of Community Based Tourism towards the development of Historical Beach tourism areas. Tourist attractions on the economic aspect, the more tourists who come to visit tourist attractions because of the attractiveness that offers it, income of the community will increase. Then tourist attractions on the socio-cultural aspects of the study area for local products or community handicrafts have not been implemented, thus hampering the income of the surrounding community or craft activists. Amenity to the economic aspect, managers who are assisted by the local government can improve services and facilities and innovation of tourism activities to attract tourists to visit beach attractions. Amenity to the socio-cultural aspect, culture owned by the community is the coastal Malay culture which has great potential as an attraction for tourists to come to tourist objects as well as develop regional economic growth.
\end{abstract}

Key Words: Community Based Tourism, Tourist Attractions, Amenities, Economic Aspects, Socio-Cultural Aspects.

\section{INTRODUCTION}

The existence of tourist destinations is one of the supporters of economic movement to encourage the government to develop tourism potential and improve the quality of life of the surrounding community (Ginting \& Septilia, 2019).

Historically, important world cities are located not far from the sea because this area has the potential of marine and fishery resources, as well as facilitate trade between regions, islands and continents. With various richness of biodiversity and the environment, coastal and marine resources have high economic and ecological value (Santi, E. \& Suib, 2017).

Thus, Government must involve and cooperate with local communities for decision-making and planning in tourism development so that it is in accordance with what is expected by each party (Hose, 2006). Community involvement in the tourism industry can also be seen from the decision-making process in the tourism development process in their environment, which will generate profits and reduce the negative impacts of tourism. (Ginting \& Selly, 2016).

With the area and length of the coast, Batu Bara Regency has a very large potential, including capture fisheries resources and aquaculture resources which are quite high. In addition, it has the 
potential of the beach to be developed as a location for beach tourism \& marine tourism. However, the potential that exists in the area does not affect the surrounding community.

Many people are economically low and unemployed. One of them is the Historical Beach which is an icon of coal and there are historical relics in the form of Japanese bunkers and have potential natural resources that can be an attraction for tourists who come. Based on the background, the problems that will be answered in this research can be formulated, namely how is the development of historical beach tourism based on Community Based Tourism?

\section{LITERATURE REVIEW \\ Development of Coastal Tourism}

Tourism development has a very broad and significant effect on economic and environmental development and has a positive impact on the socio-cultural life of the community, especially local communities. With the development of tourist areas, they are able to contribute to regional income, open business opportunities and employment opportunities and will be very relevant if they are in accordance with the potential of the area (Muksin, 2016). There are two aspects of Coastal Tourism Destination Development that will be discussed, namely: 1) Tourist Attraction Aspects, and 2) Amenity Aspects. Each of these aspects is described as follows:

\section{Aspects of Tourist Attractions}

Tourist attractions or attractions are very influential in the development of tourist destinations to bring in more tourists. Tourist attraction is something that can be enjoyed and done by tourists who have uniqueness and beauty such as natural beauty, heritage of historical buildings, local community culture and man-made attractions such as games and entertainment facilities that are the target of tourist visits (Rossadi \& Widayati, 2018).

\section{Aspects of Amenity}

Amenity aspect is an aspect that has a very big role for tourists who will visit a destination. Facilities that are managed properly will make tourists have a positive impression of a tourist spot, so that tourists will visit again. The facilities can also increase the interest and loyalty of tourists (Zaenuri, 2012).

\section{Community Based Tourism}

Community based tourism is a type of tourism that involves the community in the process of identifying problems and potentials in the community, selecting and making decisions about alternative solutions to deal with problems, implementing efforts to overcome problems, and community involvement in the process of evaluating changes that occur. (Handayani \& Priyono, 2016). This tourism development emphasizes the participation of local communities in the development process, where the community takes the initiative to participate in managing tourism in order to improve the quality of life of the community (Rusnanda et al., 2014).

In improving the economic conditions of local communities, this type of community-based tourism is also effectively implemented as tourism development (Goh, 2015). Community based tourism is a strategy for community organizations in order to achieve better living conditions so that they can provide benefits, from the economic, socio-cultural and environmental aspects in a sustainable manner. (López et al., 2011).

The goal of Community Based Tourism is to create a more sustainable tourism industry with a focus on accepting the community in terms of planning and maintaining tourism development. The community must benefit from tourism development, if this tourism is to be sustainable in the long term (Salazar, 2012).

The authors conclude several dominant aspects. The aspects of community-based tourism are 1) Economic 
Aspects, and 2) Socio-Cultural Aspects. Each aspect is explained as follows:

\section{Economic Aspects}

Tourism development creates higher incomes for local communities and opens up many job opportunities in which the local people's standard of living can be improved (Barkauskasa, Barkauskiene, and Jasinskas, 2015). Coastal tourism areas have a positive impact on local communities who initially only relied on living in the agricultural sector, construction workers and fisheries, with the beach tourism community having the opportunity to develop new businesses (Pramusita, et al. 2018).

\section{Socio-Cultural Aspects}

Socio-culture relates to attitudes and cultural values in community groups (Sulistyadi et al, 2019). Indonesia's cultural diversity is a valuable asset in developing tourism in Indonesia. Tourism that focuses on customs and socio-cultural diversity of local communities. This happens when the community participates creatively, regardless of ethnicity, religion, race and culture (Listyaningsih, 2014).

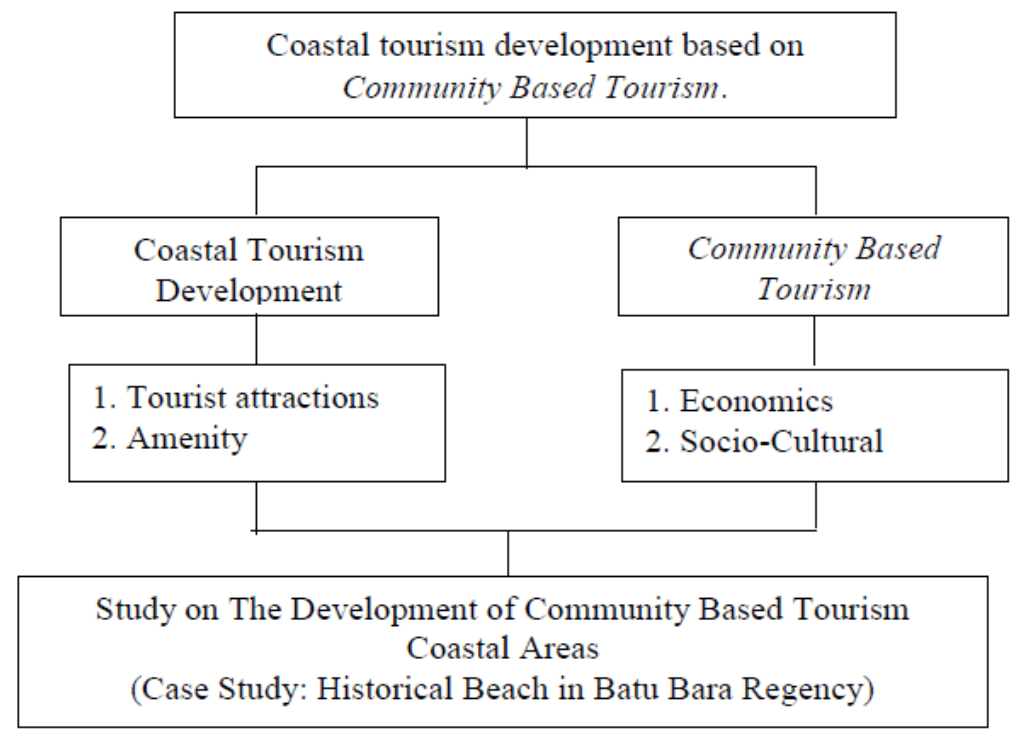

Figure 1 Theoretical Framework

\section{MATERIALS AND METHODS}

The variables of coastal tourism development and community participation were crossed to obtain the variables that will be used in this study. This cross is adjusted according to the indicators of each variable. The results of these crosses are then used as an indicator of coastal tourism development research based on Community Participation in Batu Bara Regency. The variables and indicators used in this study are as follows:

1. Tourist attractions on the economic aspect.

2. Tourist attractions on the socio-cultural aspects.

3. Amenity on the economic aspect.

4. Amenity on the socio-cultural aspects.
In this study the Slovin Method was used to determine the sample size. In this method, the population size is the basis for the sample size of an area. Total population of Parupuk Puluh Village is 2,312 residents to take the sample size following formula is used:

$$
\begin{aligned}
& n=\frac{N}{1+N(e)^{2}} \\
& n=\frac{2312}{1+2312(10 \%)^{2}}=95,85 \approx 96 \text { sample }
\end{aligned}
$$

The primary data collected by the researcher was in the form of qualitative data, namely field observations and interviews, and quantitative data, namely questionnaires. Secondary data in this study are supporting data collected by authors through literature review and statistical data related to Batu Bara Regency. 
Ivany Hidayat et.al. Study on the development of community based tourism coastal areas (case study: historical beach in Batu Bara Regency).

\section{STATISTICAL METHODS}

The results of analysis aim to produce findings, conclusions, and recommendations on the study of the development of coastal tourism areas based on Community Based Tourism as follows.

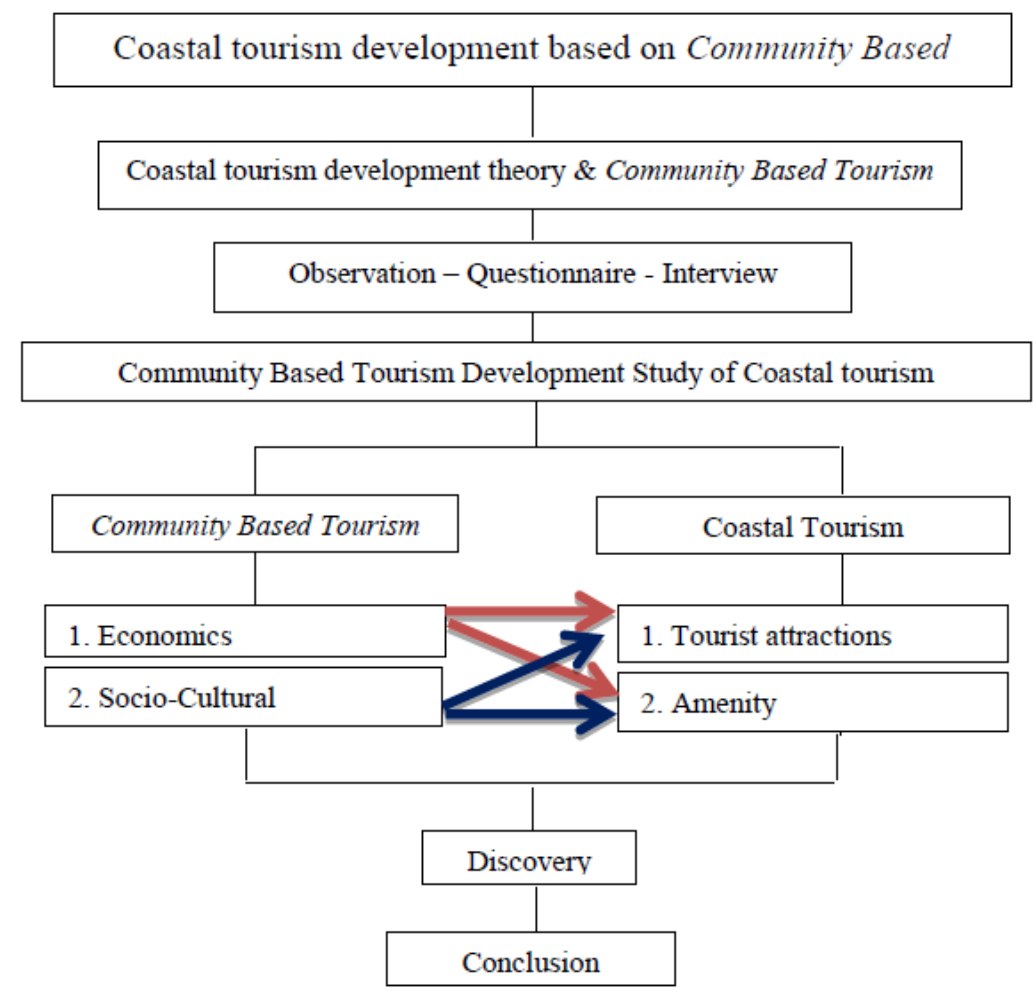

Figure 2 Data Analysis Method

\section{RESULT}

\section{Tourist Attractions}

Historical beach tourism objects have their uniqueness and beauty which causes people to be interested in visiting these tourist destinations. The more tourists who come to visit tourist attractions because of the attractiveness offered, the income will increase. Based on the results of the questionnaire, respondents think that tourist attractions on historical beaches have considered the economic aspect in their implementation $(3,86)$.

Table 1 Study Of Tourist Attractions Based On Economic Aspects

\begin{tabular}{|l|l|l|}
\hline Nu. & Statement & $\begin{array}{l}\text { Average } \\
\text { Value }\end{array}$ \\
\hline 1 & Employee and managers of tourist attractions involve local community in tourism activities. & 4,48 \\
\hline 2 & The culinary history of the coastal area can be an attraction for tourists. & 4,15 \\
\hline 3 & In the coastal area there is the marketing of local products better known by tourists as an attraction. & 3,67 \\
\hline 4 & $\begin{array}{l}\text { There are souvenir products typical of the historical beach area that have been sold outside the area by local } \\
\text { community. }\end{array}$ & 3,15 \\
\hline \multicolumn{2}{|l|}{ Average } & 3.86 \\
\hline
\end{tabular}

In tourism attractions based on socio-cultural, there are three indicators, namely local products, events, and beach activities. Historical Beach tourism objects have historical values that make them attractive to visit these tourist destinations.

The more tourists who come because of the socio-cultural attraction on offer, the more the income of the community will increase. Based on the results of the distribution of the questionnaire, the respondents argued that tourist attractions on Historical Beache have considered sociocultural aspects in their implementation $(3,73)$. 
Ivany Hidayat et.al. Study on the development of community based tourism coastal areas (case study: historical beach in Batu Bara Regency).

Table 2 Study of Tourist Attractions Based on Socio-Cultural Aspects

\begin{tabular}{|l|l|l|}
\hline No. & Statement & Average Value \\
\hline 1 & Local communities are given the opportunity to participate in coastal tourism development. & 4,57 \\
\hline 2 & There are events held in the coastal area involving the local community. & 2,76 \\
\hline 3 & The products sold in the souvenir shop are made by local community. & 4,18 \\
\hline 4 & The local community introduces the local traditions. & 3,65 \\
\hline 5 & There is beach activity in the Historical Beach area which adds to the appeal. & 3,49 \\
\hline Average & 3,73 \\
\hline
\end{tabular}

\section{Amenitas}

The amenity aspect is the most important aspect in tourism development which aims to provide facilities and accommodate the activities of tourists while in the tourist spot. These facilities are one of the considerations of tourists in visiting a tourist attraction.

If the facilities are good, then the tourist attractions will become the center of attention and attract many visitors. On the other hand, if the facilities are weak, the tourist attractions will be far from the interest of visitors so that tourists look for other places to get tourist satisfaction (Lanzara \& Minerva, 2018).

Based on the results of distributing questionnaires, respondents think that the Historical Beach amenities have not taken into account the economic aspects in their implementation $(3,61)$.

Table 3 Study of Amenities Based on Economic Aspects

\begin{tabular}{|l|l|l|}
\hline Nu. & Statement & Average Value \\
\hline 1 & There are activities to increase the results of community handicrafts in the historical coastal area. & 3,76 \\
\hline 2 & Local communities have been given the opportunity to open businesses in recreational areas. & 4,75 \\
\hline 3 & The gazebo/hut facilities provided are very interesting. & 2,48 \\
\hline 4 & The gazebo/cottage facilities provided are very comfortable to use for resting. & 2,52 \\
\hline 5 & The local community has been given the opportunity to create products to sell. & 4,58 \\
\hline \multicolumn{2}{|l|}{ Average } & 3,61 \\
\hline
\end{tabular}

Based on the results of the questionnaire distribution, respondents were of the opinion that not all of the historical beach amenities have taken into account socio-cultural aspects in their implementation $(3,57)$. Some of the indicators of this socio-cultural aspect are indicators of supporting facilities and preserving local culture.

Table 4 Study of Amenity Based on Socio-Cultural Aspects

\begin{tabular}{|l|l|l|}
\hline Nu. & Statement & Average Value \\
\hline 1 & The architectural style of the place to eat shows the characteristics of local culture. & 3,25 \\
\hline 2 & The architectural style of the rest area/gazebo shows the characteristics of local culture. & 3,18 \\
\hline 3 & There is a souvenir shop that sells products with local characteristics (such as Ulos) in the beach area. & 3,86 \\
\hline 4 & I am satisfied with the level of cleanliness at this recreation area. & 3,98 \\
\hline \multicolumn{2}{|l}{ Average } & 3,57 \\
\hline
\end{tabular}

\section{DISCUSSION}

Study of Tourist Attractions Based on Economic Aspects

The existence of historical coastal culinary areas can be an attraction for tourists from the results of the questionnaire having an average value of 4,16 (Table 1).
In Historical Beach area in Batu Bara Regency, the sea products produced by the beach are in the form of shells such as kepah, mentarang and stone shells which are typical of the coast and become an attraction for visitors, as shown in the following picture. 


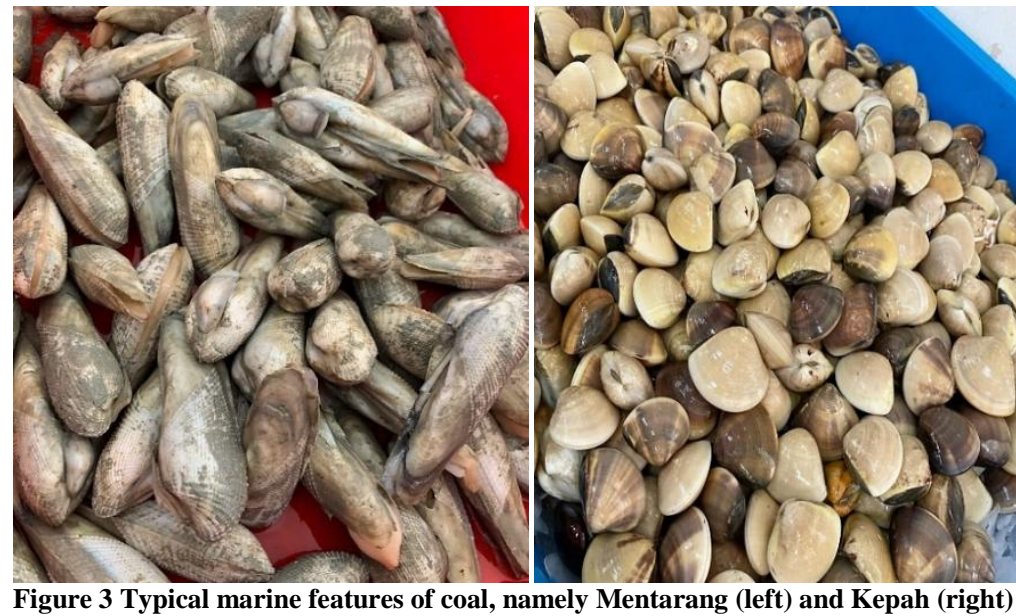

In the coastal area there is marketing of local products so that they are better known by tourists as an attraction from the results of the questionnaire obtaining an average score of 3,67 (Table 1). Based on field observations of the Historical Beach tourist attraction in. Batu Bara Regency, marketing of local community products that can increase tourism in the Regency. Coal has not been implemented in the study area. So that there are still people who are confused about marketing their craft products.

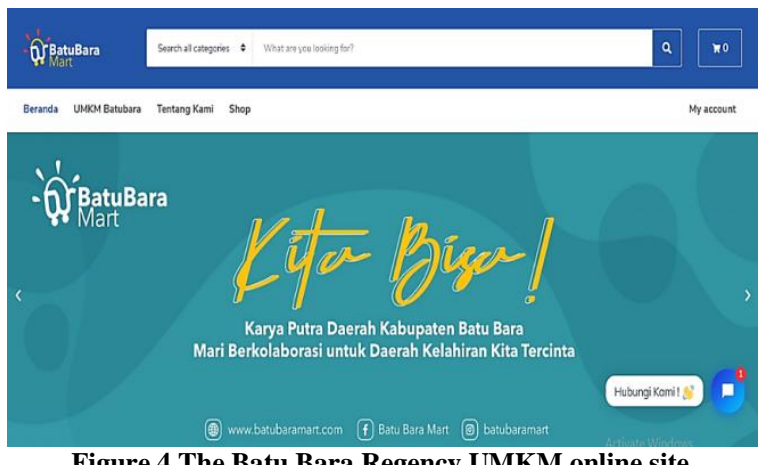

Figure 4 The Batu Bara Regency UMKM online site Source: Coal mart.com

To improve the standard of living of the local community, ideally the products that have been made should be marketed outside the region. Based on the results of the questionnaire on the statement that souvenir products typical of the historical coastal area have been sold outside the region, the average value is 3,15 which states that there are no local products such as souvenirs that are characteristic of the beach which are marketed outside region (Table 1).

\section{Study of Amenity Based on Economic Aspect}

The presence of tourists will be accompanied by the growing needs of tourists which can create business opportunities for the local community. Activities to increase the results of community handicraft products in historical coastal areas, from the results of the questionnaire conducted by 96 respondents had an average value of 3,76 (Table 3). This is also supported based on field observations on historical beach tourism objects that by increasing the results of community handicraft products can improve the quality of life of local communities.

In the study area, the culinary business carried out by the community is in the form of selling staple foods to some selling children's toys and miniature crafts 
such as miniature Malay traditional houses,

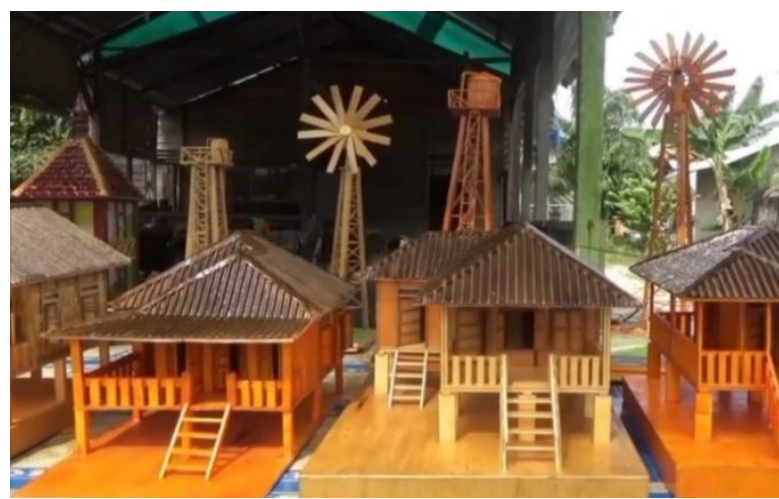

Figure 5 Miniature of processed wood waste

Apart from creating local products, improving the standard of living of the community can also be done through the opportunity to open a business in recreational areas. Based on the results of mosques, decorative lamps made of wood.

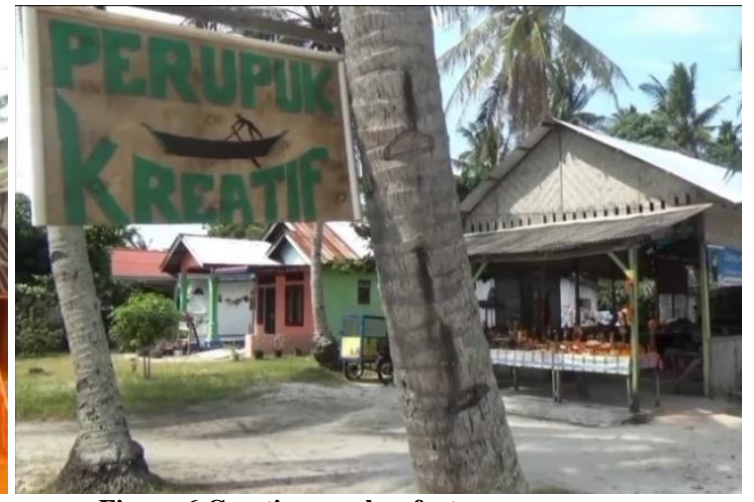

Figure 6 Creative cracker factory

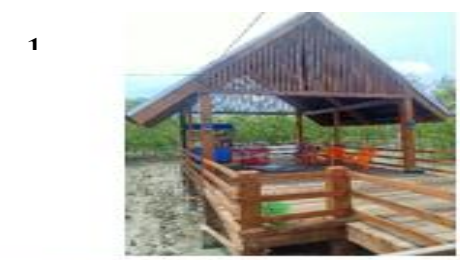

the questionnaire (Table 3), the local community strongly agrees with the opportunity to open a business. From the results of the questionnaire, the average value is 4,75 .
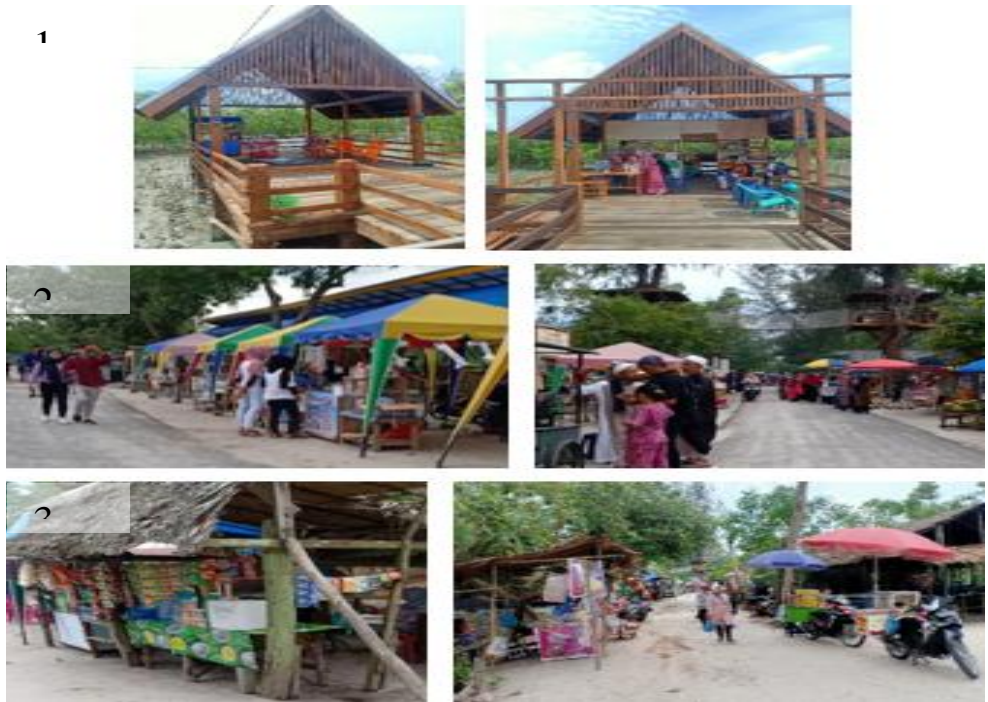

Figure 7 The condition of the selling area in Historical Beach attractions

However, in the area, the beach is last attraction after attraction of the production bridge and the hanging bicycle and flying fox attractions. It is because the gazebo/hut facilities provided are not comfortable to use for resting (average value 2,52) and the appearance is not attractive (average value 2,48).

There are still many huts that have never been updated from ancient times to the present. The huts are made of logs and roofed with thatch leaves. Even roof of the hut was damaged and the wood as a barrier to the hut was slanted. So when it rains the visitors can not take shelter in the hut.

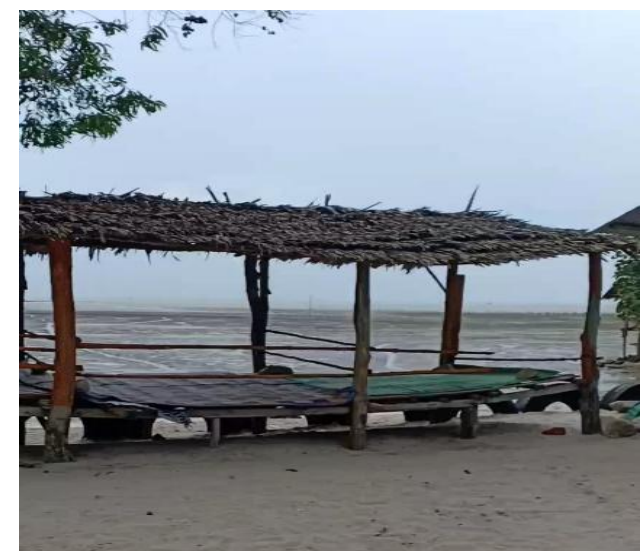

Figure 8 Cottage/gazebo facilities in the historical beach area 
The presence of tourists will be accompanied by the growing needs of tourists which can create business opportunities for the local community. So that the local community has been given the opportunity to create products to sell 4.58 (table 5.2). This is also supported based on field observations on Historical Beach tourism objects that by developing local products can improve the quality of life of local people.

\section{Study of Tourist Attractions Based on Economic Socio-Cultural Aspects}

Local community introduces the traditions of the area to tourists. From the results of the response has an average value of 3.65 (table 2). Where culture is passed down from generation to generation it will become a tradition. Local cultural traditions will be an important attraction for tourists to visit the area (Jupir, 2013).

The cultural tradition carried out by local community in Batu Bara Regency is the Lemang Tapai Party Tradition. This is supported by the results of observations in the study area, where around the beach there is a tradition of the lemang tapai party which is carried out by residents in front of their homes when welcoming the holy month of Ramadan until the eve of Eid alFitr.

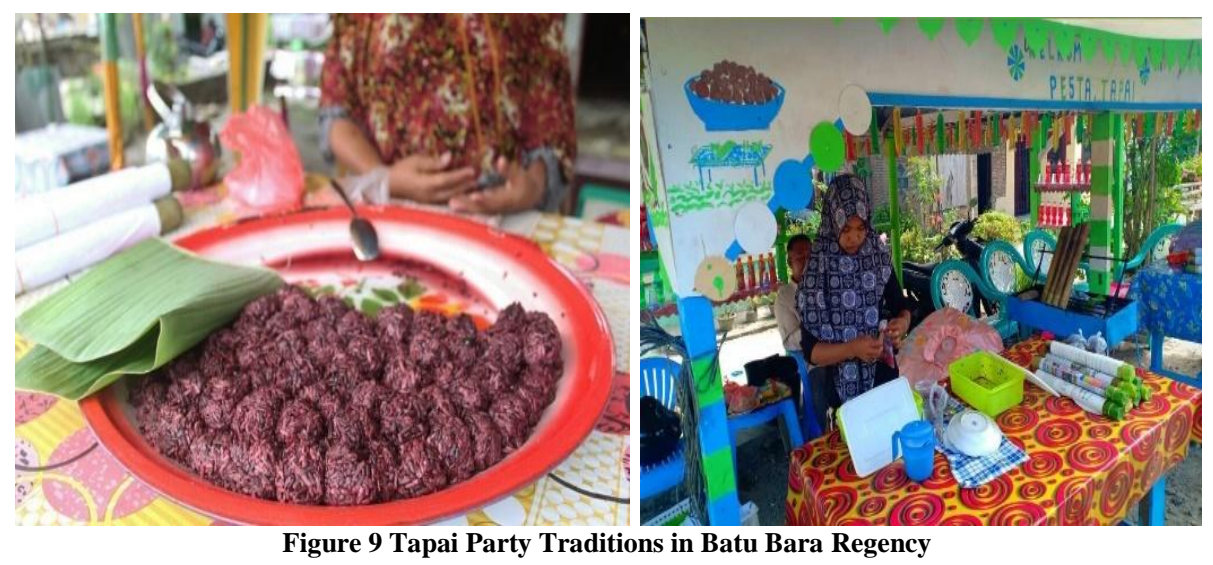

Lots of teenagers and parents taking selfies on the bridge. This bridge is in a mangrove forest area that stretches to the middle of the sea. This is conveyed by the manager of the beach.
“... a lot of visitors come to enter the bridge area. Initially this bridge was built to make it easier for fishermen to find marine animals, not for tourists. But it's the other way around..."
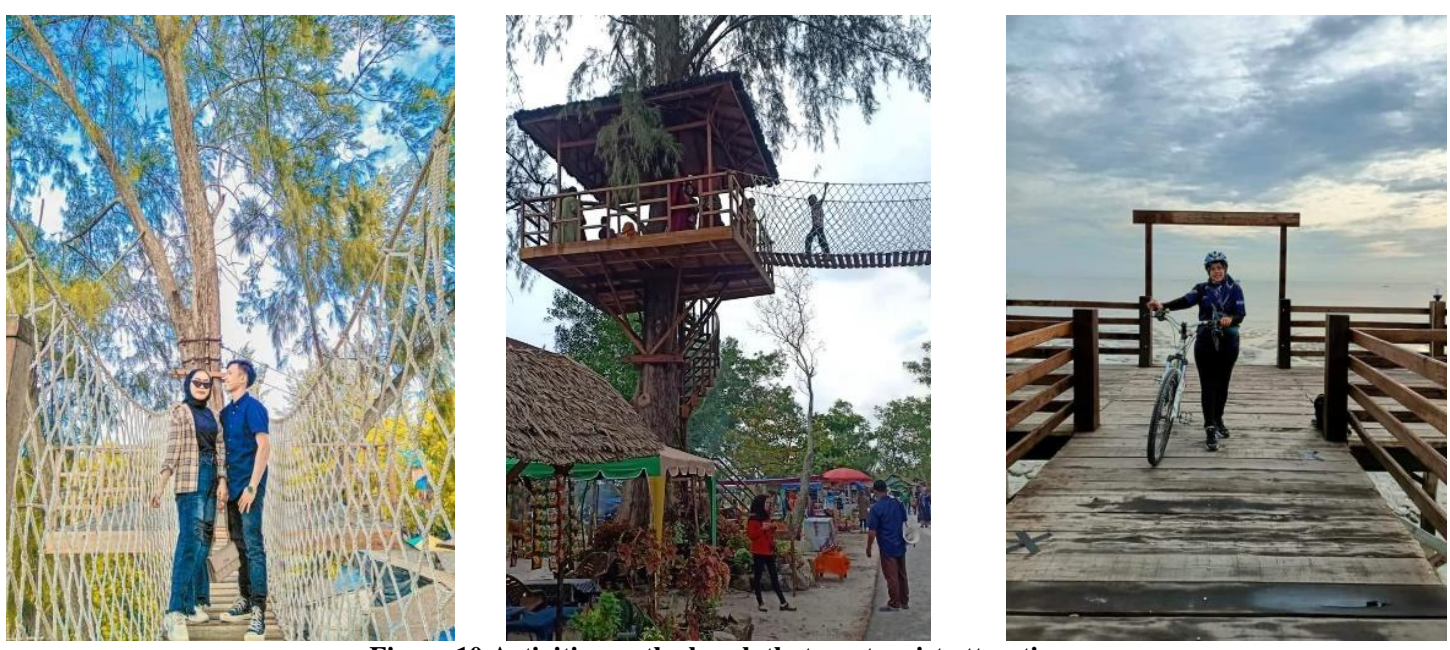

Figure 10 Activities on the beach that are tourist attractions 
In an effort to revive the Malay culture, it is necessary to have events that can attract the attention of tourists to visit. Historical Beach is one of the areas with great potential as a place to liven up Malay cultural events by carrying out its coastal Malay culture arts. However, it is very unfortunate that until now there has been no routine event held to revive the Malay cultural activities.

\section{Study of Amenity Based on Socio- Cultural Aspect}

Based on the results of the questionnaire, respondents thought it was normal/neutral that there was a cultural emphasis on these facilities (3.25 dining places; 3.18 rest areas/gazebos). Respondents' opinion can be supported by observations at the two facilities, where the architectural style used does not reflect the Malay culture but uses sustainable architecture.

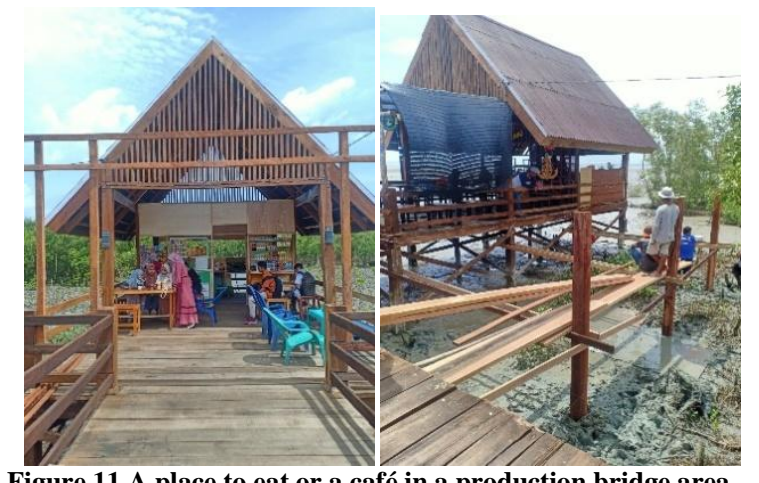

Figure 11 A place to eat or a café in a production bridge area

Markwick, (2018), explains that everything related to local culture will attract tourists. Products with local cultural characteristics will be special items that tourists get from somewhere. Songket cloth is one of the traditional fabrics which is a cultural heritage in Indonesia. Each region has its own unique style and motif, such as the coal songket cloth in North Sumatra.

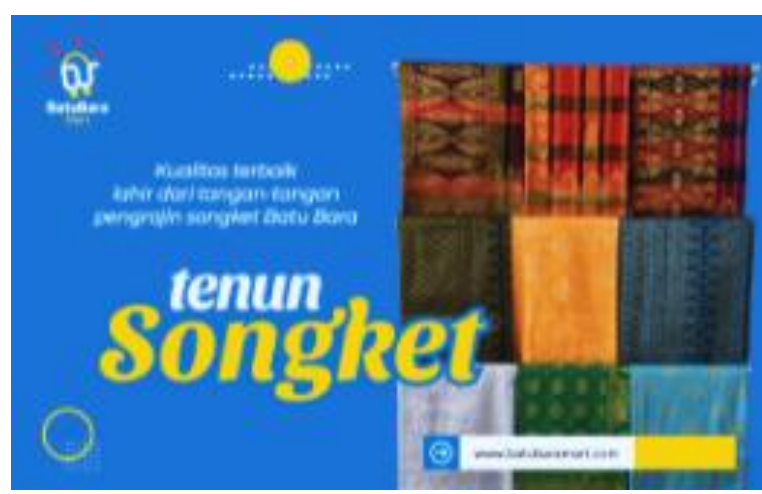

Figure 12 Coal Songket Cloth, North Sumatra Source: www.batubaramart.com

According to Table 4, the level of cleanliness in this recreation area. has an average value of 3.98. It can be concluded that the respondents agree that the clean beach tourism area and the availability of cleaning support facilities make the attraction of the beach tourism area. However, there are also some dirty ones. With a clean tourism area, it will create a good impression for every tourist who visits the place (Rahmawati \& Hakim, 2017).

This is supported by observations at tourist objects, that a clean historical beach area will become a tourist attraction. However, at some points there is a build-up of garbage, namely in the mangrove conservation area and in the beach area, trash can still be seen scattered on the shore.
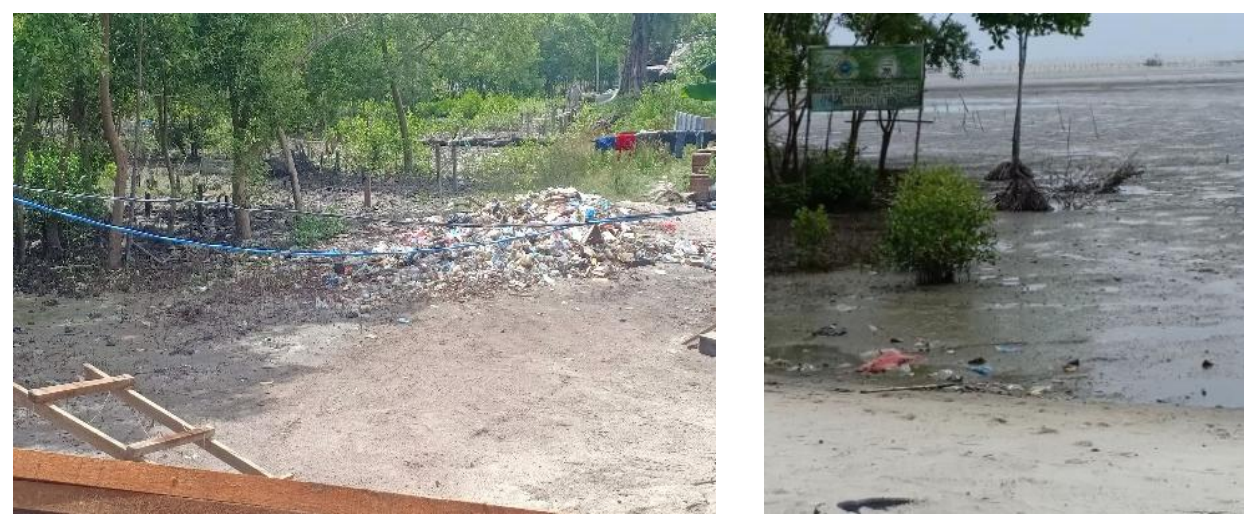

Figure 13 Garbage Accumulation at Historical Beach, Batu Bara Regency 


\section{CONCLUSION}

Based on the discussion has been described above, the authors conclude four things related are as follows:

1. Tourist attractions on the economic aspect, historical beach tourism objects have their uniqueness and beauty which causes people to be attracted to visit these tourist destinations. The more tourists who come to visit tourist attractions because of the attractiveness offered, the income will increase.

2. Tourist attractions to socio-cultural aspects of the study area for local products or handicrafts have not been implemented, thus hampering the income of the surrounding community or craft activists. In fact, the community has the skills to make woven mats typical of the coal area or handicrafts from used waste that is found around their environment.

3. Amenities to economic aspects, managers who are assisted by the local government can improve services and facilities. In improving the facilities provided, such as cottages or gazebos, renovations were carried out, so that tourists who came felt comfortable using them. The available eating places in the study area are still inadequate, there are only six small huts that have just been built in the production bridge section. But not on the beach.

4. Amenities on the socio-cultural aspect, the culture owned by coastal community is the coastal Malay culture which has great potential as an attraction for tourists to come to tourist objects while developing the economic growth of the region. The fact is that until now, the culture community can create opportunities for tourists has not been seen in the area.

\section{RECOMMENDATION}

Based on the conclusions above, the authors put forward the following suggestions:

\section{The Academies}

1. The next researchers to be able to study more deeply and study the phenomena that exist in society and the environment of the Coastal Zone.

2. Future researchers can multiply the variables that are adjusted to field conditions so that the results of the next research can be seen and assessed with a broader perspective.

\section{The Government}

1. The Department of Tourism and Creative Economy of Batu Bara Regency can maximize performance by making policies related to the development of historical beach tourism.

2. Monitoring and evaluating the development of the Historical Coast in terms of community services, number of visits, tourist satisfaction, and environmental conditions.

3. The cultural potential of tourist destinations will open up job opportunities for art activists. The government should be able to support art galleries to be actively involved in it.

\section{The Community}

1. The need for public awareness and responsibility in maintaining the preservation of Historical Beach as a marine tourism destination.

2. Create a community agency or tourism awareness group with a clear organizational structure and divided into several working groups.

\section{Acknowledgement: None}

\section{Conflict of Interest: None}

\section{Source of Funding: None}

\section{REFERENCES}

1. Abdillah, D. (2016). Pengembangan Wisata Bahari di Pesisir Pantai Teluk Lampung. Jurnal, 1 .

2. Abdulhaji, S., \& Yusuf, I. S. H. (2017). Pengaruh atraksi, aksesibilitas dan fasilitas terhadap citra objek wisata Danau Tolire 
Ivany Hidayat et.al. Study on the development of community based tourism coastal areas (case study: historical beach in Batu Bara Regency).

Besar di Kota Ternate. Humano: Jurnal Penelitian, 7(2), 134-148.

3. Amalyah, R., Hamid, D., \& Hakim, L. (2016). Peran Stakeholder Pariwisata Dalam Pengembangan Pulau Samalona Sebagai Destinasi Wisata Bahari. Jurnal Administrasi Bisnis, 37(1), 158-163.

4. Amir, S., Osman, M. M., Bachok, S., \& Ibrahim, M. (2015). Sustaining local community economy through tourism: Melaka UNESCO world heritagecity. Procedia Environmental Sciences, 28, 443452.

5. Aytuğ, H. K., \& Mikaeili, M. (2017). Evaluation of Hopa's Rural Tourism Potential in the Context of European Union Tourism Policy. ProcediaEnvironmental Sciences, 37, 234-245.

6. Badan Pusat Statistik Kabupaten Batu Bara. (2020). Batu Bara Dalam Angka 2017. Lima Puluh.

7. Barkauskas, V., \& Jasinskas, E. (2015). Analysis of macro environmental factors influencing the development of rural tourism: Lithuanian case. Procedia-Social and Behavioral Sciences, 213, 167-172.

8. Beramas, S. (2019). Analisis Sustainable Tourism pada Kawasan Wisata Tanjung Setia di Kabupaten Pesisir Barat.

9. Boedirachminarni, A., \& Suliswanto, M. S. W. (2017). Analisis Kepuasan Pengunjung Ekowisata Kabupaten Malang. Jurnal Ekonomi Pembangunan, 15(1), 101-112.

10. Brandão, F., Breda, Z., \& Costa, C. (2019). Innovation and internationalization as development strategies for coastal tourism destinations: The role of organizational networks. Journal of Hospitality and Tourism Management.

11. Chen, C. L., \& Teng, N. (2016). Management priorities and carrying capacity at a high-use beach from tourists' perspectives: A way towards sustainable beach tourism. Marine Policy, 74, 213-219.

12. Cuccia, T., \& Rizzo, I. (2011). Tourism seasonality in cultural destinations: Empirical evidence from Sicily. Tourism Management, 32(3), 589-595.

13. Dalimunthe, D. Y., Sulistiana, I., \& Fahria, I. (2017). Analisi Ekonomi Sumber Daya Kawasan Konservasi Laut Marine Protected Area (MPA) Melalui Pemberdayan Masyarakat Pesisirdan Pengembangan Wisata Bahari. Jurnal Pengabdian Kepada
Masyarakat Universitas Bangka

Belitung, 4(1).

14. Dimoska, T., \& Petrevska, B. (2012). Indicators for sustainable tourism development in Macedonia. In Conference Proceedings (pp. 389-400). Goce Delcev University, Faculty of Economics.

15. Elfianita, E. (2016). Pengembangan Pariwisata Berbasis Community Based Tourism (CBT) di Desa Wisata Limbasari Kecamatan Bobotsari, Kabupaten Purbalingga. Jurnal Elektronik Mahasiswa Pend. Luar Sekolah-S1, 5(3).

16. Fachrudin, H. T., \& Lubis, M. D. (2016). Planning for riverside area as water tourism destination to improve quality of life local residents, case study: Batuan-Sikambing River, Medan, Indonesia. Procedia-Social and Behavioral Sciences, 234, 434-441.

17. Fauzi, F. (2016). Analisis potensi wisata Situ Ciledug dan Situ Gintung di Kota Tangerang Selatan. Pro-Life, 3(2), 83-96.

18. Farhan, H., \& Anwar, K. (2016). The Tourism Development Strategy Based on Rural and Local Wisdom. Journal of Sustainable Development, 9(3),170.

19. Ginting, N., \& Septilia, T. (2019). Tourists perception toward public open space's physical elements (case study: Cermin beach). IOP Conference Series: Materials Science and Engineering, 505(1),012-112.

20. Ginting, N., Vinky Rahman, N., Sembiring, G. (2017). Tourism Development Based on Geopark in Bakkara Caldera Toba, Indonesia. IOP Conference Series: Materials Science and Engineering, 180 (1),012-086.

21. Ginting, N., \& Veronica, S. (2016). Pariwisata Berbasis Masyarakat Pasar Buah Berastagi. Proceeding Temu Ilmiah IPLBI.

22. Ginting, N., \& Wahid, J. (2015). Exploring Identity's Aspect of Continuity of Urban Heritage Tourism. Procedia-Social and Behavioral Sciences, 202, 234-241.

23. Goh, H. C. (2015). Nature And CommunityBased Tourism (CBT) For Poverty Alleviation: A Case Study Of Lower Kinabatangan, East Malaysia. Malaysian Journal of Society and Space, 11(3), pp. 42 -52 .

24. Handayani, G, \& Priyono, K. D. (2016), Evaluasi Potensi Kawasan Kotagede Sebagai Destinasi Wisata Berbasis Warisan Budaya (Heritage Tourism) Daerah 
Istimewa Yogyakarta, Disertasi, Universitas Muhammadiyah Surakarta.

25. Ismail, W. A. W., \& Said, I. (2015). Integrating the community in urban design and planning of public spaces: a review in Malaysian cities. Procedia-Social and Behavioral Sciences, 168, 357-364.

26. Jupir, M. M. (2013). Implementasi kebijakan pariwisata berbasis kearifan local (Studi di Kabupaten Manggarai Barat). Journal of Indonesian Tourismand Development Studies, 1(1), 28-38.

27. Lane, B., \& Kastenholz, E. (2015). Rural tourism: The evolution of practice and research approaches-towards a new generation concept? Journal of Sustainable Tourism, 23(8-9), 1133-1156.

28. Lanzara, G., \& Minerva, G. A. (2019). Tourism, amenities, and welfare in an urban setting. Journal of Regional Science, 59(3), 452-479.

29. Latupapua, Yosevita Th. (2011). Persepsi Masyarakat terhadap Potensi Objek Daya Tarik Wisata Pantai di KecamatanKei Kecil Kabupaten Maluku Tenggara. Jurnal Agroforesty ISSN, 1907-7556.

30. Listyaningsih. 2014. Administrasi Pembangunan "Pendekatan Konsep dan Implementasi". Yogyakarta: Graha Ilmu.

31. Lestari, G., Armawi, A., \& Muhamad, M. (2016). Partisipasi Pemuda Dalam Mengembangkan Pariwisata Berbasis Masyarakat Untuk Meningkatkan Ketahanan Sosial Budaya Wilayah (Studi di Desa Wisata Pentingsari, Umbulharjo, Cangkringan, Sleman, DI Yogyakarta). Jurnal Ketahanan Nasional, 22(2), 137-157.

32. López-Guzmán, T., Sánchez-Cañizares, S., \& Pavón, V. (2011). Community-based tourism in developing countries: a case study. Tourismos, 6(1).

33. Markwick, M. (2018). Valletta ECoC 2018 and cultural tourism development. Journal of Tourism and Cultural Change, 16(3), 286-308.

34. Marwasta, D. (2017). Pendampingan Masyarakat Desa Parangtritis dalam Pengelolaan Kawasan Gumuk Pasir melalui kegiatan Diversifikasi Usaha Berbasis Sumberdaya Pesisir. Jurnal Pengabdian kepada Masyarakat (Indonesian Journal of Community Engagement), 2(2), 133-145.

35. Mowforth, M., \& Munt, I. (2016). Hosts' and Destinations: for What we are About to Receive.. Tourism and Sustainability:
Development, Globalisation and New Tourism in the 3rd World.

36. Muksin, D. 2016. Stategi Pengembangan Kawasan Pariwisata Gunung Galunggung. Studi Kasus Kecamatan Sukaratu Kabupaten Tasikmalaya. Bandung.

37. Mustapha, M., Zulkifli, F. Z., \& Awang, K. W. (2018). Enhancing sustainability through implementation of balanced scorecard: A case study of beach resorts. Journal of Sustainability Science and Management, 5, 136-147.

38. Nowacki, M. (2013). The Determinants of Satisfaction of Tourist Attractions Visitors.

39. Pinto, Z. (2015). Kajian Perilaku Masyarakat Pesisir yang Mengakibatkan Kerusakan Lingkungan (Studi Kasus di Pantai Kuwaru, Desa Poncosari, Kecamatan Srandakan, Kabupaten Bantul, Provinsi DIY). Jurnal Wilayah dan lingkungan, 3(3), 163-174.

40. Pramusita, A., \& Sarinastiti, E. N. (2018). Aspek sosial ekonomi masyarakat lokal dalam pengelolaan Desa Wisata Pantai Trisik, Kulonprogo. Jurnal Pariwisata Terapan, 2(1), 14-25.

41. Rahmawati, S. W., Sunarti, S., \& Hakim, L. (2017). Penerapan Sapta Pesona Pada Desa Wisata (Analisis Persepsi Wisatawan atas Layanan Penyedia Jasa di Kampung Wisata Kungkuk, Desa Punten, Kota Batu). Jurnal Administrasi Bisnis, 50(2), 195-202.

42. Richards, G. (2018). Cultural tourism: A review of recent research and trends. Journal of Hospitality and Tourism Management, 36, 12-21.

43. Rohmadin, S. (2016). Strategi pengembangan kawasan wisata berbasis pembangunan berkelanjutan di Kabupaten Ende Provinsi Nusa Tenggara Timur. Jurnal Politik Pemerintahan, 9(1), 141-153.

44. Rossadi, L. N., \& Widayati, E. (2018). Pengaruh aksesibilitas, amenitas, dan atraksi wisata terhadap minat kunjungan wisatawan ke Wahana Air Balong Waterpark Bantul Daerah Istimewa Yogyakarta. Journal of Tourism and Economic, 1(2).

45. Rusnanda, R. (2014). Kajian Potensi Wisata Kota Tapaktuan, Berbasis Masyarakat Lokal (Master's thesis).

46. Rusnanda, R., Ginting, N. \& Wahid, J. (2014). Kajian Potensi Wisata Tapaktuan Berbasis Masyarakat Lokal. Jurnal Raut, 1(2), pp. 59-72. 
47. Saad, Z.I., \& Yenida. (2018). Potensi Objek Wisata Bahari Pesisir Pantai di Kota Pariaman Sumatera Barat. Jurnal Ilmiah Poli Bisnis, 10(1).

48. Santi, E., \& Suib. (2017). Analisis Potensi Dan Permasalahan Pengembangan Wilayah Pesisir Kabupaten Batu Bara. Laporan penelitian.

49. Salazar, N. B. (2012). Community-based cultural tourism: Issues, threats and opportunities. Journal of Sustainable Tourism, 20(1), 9-22.

50. Sesotyaningtyas, M. \& Manaf, A. (2015). Analysis Of Sustainable Tourism Village Development At Kutoharjo Village, Kendal Regency of Central Java. In: Procedia Social and Behavioral Sciences 184, pp. 273 -280 .

51. Setyanto, I., \& Pangestuti, E. (2019). Pengaruh komponen destinasi wisata (4A) terhadap kepuasan pengunjung Pantai Gemah Tulungagung. Jurnal Administrasi Bisnis, 72(1), 157-167.

52. Shaffril, H. A. M., Hamzah, A., Md. Yassin, S., Abu Samah, B., D'Silva, J. L., Tiraieyari, N., \& Muhammad, M. (2015). The coastal community perception on the socioeconomic impacts of agro-tourism activities in coastal villages in Malaysia. Asia Pacific journal of tourismresearch, 20(3), 295-313.

53. Sinaga, F. A. (2019). Kajian Pengembangan Geotourism Bakara Berbasis Masyarakat.

54. Sulistyadi, Y. dkk. (2019). Pariwisata Berkelanjutan dalam Perspektif Pariwisata Budaya di Taman Hutan Raya Banten. Uwais Inspirasi Indonesia. Sunarta, N. dan Arida, N. S., 2017. Pariwisata Berkelanjutan. Bali: Cakra Press.

55. Susanto, D. R., \& Syaifulloh, M. (2018). Pengembangan Obyek Wisata Berbasis Community Based Tourism (CBT) Di Hutan Payau, Cilacap. Kepariwisataan: Jurnal Ilmiah, 12(2).

56. Valle, P. O. D., Guerreiro, M., Mendes, J., \& Silva, J. A. (2011). The cultural offer as a tourist product in coastal destinations: The Case of Algarve, Portugal. Tourism and Hospitality Research, 11(4), 233-247.
57. Vengesayi, Sebastian. 2003. "A Conceptual Model of Tourism Destination Competitiveness and Attractiveness." Adelaide: ANZMAC Conference Proceeding. Page 637-647.

58. Vitasurya, V.R. (2016). Local Wisdom for Sustainable Development of Rural Tourism, Case on Kalibiru and Lopati Village, Province of Daerah Istimewa Yogyakarta. Procedia - Social and Behavioral Sciences, 216, pp. 97-108. DOI: 10.1016/j.sbspro.2015.12.014.

59. Waani, H. F. (2016). Sosial Budaya Dalam Pengembangan Pariwisata Di Kelurahan Bunaken Kecamatan Bunaken Kota Manado. ACTA DIURNA KOMUNIKASI, 5(2).

60. Widodo, E. (2017). Pengembangan atraksi wisata Pantai Tanjung Karang sebagai kawasan wisata bahari di Kabupaten Donggala. Katalogis, 5(4).

61. Wiseza, F, C., (2017). Faktor-Faktor yang mendukung pengembangan Obyek Wisata Bukit Khayangan di Kota Sungai penuh Provinsi Jambi. vol 4,1.

62. Yusof, Y., Ibrahim, Y., Muda, M. S. \& Amin, A. A. W. M. (2012). Community Based Tourism and Quality Of Life. Riview of Integrative Business \& Economic Research, 1(1), pp. 336-346.

63. Zadel, Z., Gračan, D., \& Milojica, V. (2018). Beaches as a factor in achieving competitiveness of a tourist product-case study: Istrian County. Multidisciplinary Scientific Journal of Maritime Research, 32, 102-114.

64. Zaenuri, M. (2012). Perencanaan Strategis Kepariwisataan Daerah: Konsep dan Aplikasi. Jogjakarta: e-Gov Publishing.

How to cite this article: Hidayat I, Ginting N, Fachrudin HT. Study on the development of community based tourism coastal areas (case study: historical beach in Batu Bara Regency). International Journal of Research and Review. 2021; 8(10): 141-153. DOI: https://doi.org/10. 52403/ijrr.20211019 